\title{
Thrombelastography and tromboelastometry in assessing coagulopathy in trauma
} Pär I Johansson*, Trine Stissing, Louise Bochsen and Sisse R Ostrowski

\author{
Address: Section for Transfusion Medicine, Regional Blood Bank, Rigshospitalet, University of Copenhagen, Denmark \\ Email: Pär I Johansson* - per.johansson@rh.regionh.dk; Trine Stissing - trine.stissing@rh.regionh.dk; \\ Louise Bochsen - louise.bochsen@rh.regionh.dk; Sisse R Ostrowski - sisse.ostrowski@gmail.com \\ * Corresponding author
}

Published: 23 September 2009

Scandinavian Journal of Trauma, Resuscitation and Emergency Medicine 2009, 17:45 doi:10.1 I86/1757-724I-17-45
Received: I July 2009

Accepted: 23 September 2009

This article is available from: http://www.sjtrem.com/content//7/1/45

(c) 2009 Johansson et al; licensee BioMed Central Ltd.

This is an Open Access article distributed under the terms of the Creative Commons Attribution License (http://creativecommons.org/licenses/by/2.0), which permits unrestricted use, distribution, and reproduction in any medium, provided the original work is properly cited.

\begin{abstract}
Death due to trauma is the leading cause of lost life years worldwide, with haemorrhage being responsible for $30-40 \%$ of trauma mortality and accounting for almost $50 \%$ of the deaths the initial $24 \mathrm{~h}$. On admission, $25-35 \%$ of trauma patients present with coagulopathy, which is associated with a several-fold increase in morbidity and mortality. The recent introduction of haemostatic control resuscitation along with emerging understanding of acute post-traumatic coagulability, are important means to improve therapy and outcome in exsanguinating trauma patients. This change in therapy has emphasized the urgent need for adequate haemostatic assays to monitor traumatic coagulopathy and guide therapy. Based on the cell-based model of haemostasis, there is emerging consensus that plasma-based routine coagulation tests (RCoT), like prothrombin time (PT) and activated partial thromboplastin time (APTT), are inappropriate for monitoring coagulopathy and guide therapy in trauma. The necessity to analyze whole blood to accurately identify relevant coagulopathies, has led to a revival of the interest in viscoelastic haemostatic assays (VHA) such as Thromboelastography $\left(\right.$ TEG $\left.^{\circledR}\right)$ and Rotation Thromboelastometry (ROTEM $\left.{ }^{\circledR}\right)$. Clinical studies including about 5000 surgical and/or trauma patients have reported on the benefit of using the VHA as compared to plasma-based assays, to identify coagulopathy and guide therapy.

This article reviews the basic principles of VHA, the correlation between the VHA whole blood clot formation in accordance with the cell-based model of haemostasis, the current use of VHAguided therapy in trauma and massive transfusion (haemostatic control resuscitation), limitations of VHA and future perspectives of this assay in trauma.
\end{abstract}

\section{Introduction}

On admission, $25-35 \%$ of trauma patients present with coagulopathy, which is associated with a several-fold increase in morbidity and mortality $[1,2]$. Although the management of traumatic coagulopathy differs worldwide $[3,4]$, the recent introduction of haemostatic control resuscitation [5-7] and the emerging understanding of acute post-traumatic coagulopathy $[1,2,8,9]$, emphasize the urgent need for adequate haemostatic assays to guide therapy. Classically, coagulopathy is often monitored by plasma-based routine coagulation tests (RCoT) such as activated partial thromboplastin time (APTT) and prothrombin time (PT). These assays were developed half a century ago to monitor haemophilia and anticoagulation therapy, but have unfortunately never been validated for the prediction of haemorrhage in a clinical setting 
$[10,11]$. It should be noted that although abnormal PT and APTT are highly correlated with mortality in trauma patients, the cause of death in these patients is not identified as excessive bleeding [12-14]. This lack of correlation with clinically relevant coagulopathies can be explained by the fact that plasma-based assays reflect only the small amount of thrombin formed during initiation of coagulation $[15,16]$. Consequently, recent reviews have concluded that the plasma-based assays are inappropriate for monitoring coagulopathy or guide transfusion therapy, calling for new tests to monitor these complex patients $[17,18]$.

In 1994, the classical clotting cascade of haemostasis $[19,20]$ was challenged by the introduction of a cell-based model of haemostasis emphasizing the importance of tissue factor (TF) as the initiator of coagulation and the pivotal role of platelets for intact haemostasis [21]. The poor correlation between RCoT and clinical bleeding in e.g. trauma and surgery [12-15,22-25] is, hence, explained by this new understanding of haemostasis.

The necessity to analyze whole blood to accurately identify relevant coagulopathies, has led to a revival of the interest in viscoelastic point-of-care haemostatic assays (VHA) such as Thromboelastography (TEG ${ }^{\circledR}$ ) and Rotation Thromboelastometry $\left(\right.$ ROTEM $\left.^{\circledR}\right)$.

The objective of this article is to review the basic principles of VHA, the correlation between the result of VHA and clot formation in accordance with the cell-based model of haemostasis, the current use of VHA-guided therapy in trauma and massive transfusion (haemostatic control resuscitation), limitations of VHA and future perspectives of application of this assay.

\section{Basic principles of VHA}

Thrombelastography was first described in 1948 by $\mathrm{H}$. Hartert [26], as a method to assess the viscoelastic properties of coagulation in whole blood under low shear conditions [27-31]. The VHA gives a graphic presentation of clot formation and subsequent lysis. Blood is incubated at $37^{\circ} \mathrm{C}$ in a heated cup. Within the cup is suspended a pin connected to a detector system (a torsion wire in TEG and an optical detector in ROTEM). The cup and pin are oscillated relative to each other through an angle of $4^{\circ} 45^{\prime}$. The movement is initiated from either the cup (TEG) or the pin (ROTEM). As fibrin forms between the cup and pin, the transmitted rotation from the cup to pin (TEG) or the impedance of the rotation of the pin (ROTEM) are detected at the pin and a trace generated (Figure 1). The trace is divided into parts that each reflects different stages of the haemostatic process (clotting time, kinetics, strength and lysis, Figure 1) with slightly different nomenclature for TEG and ROTEM (Table 1). Examples of traces

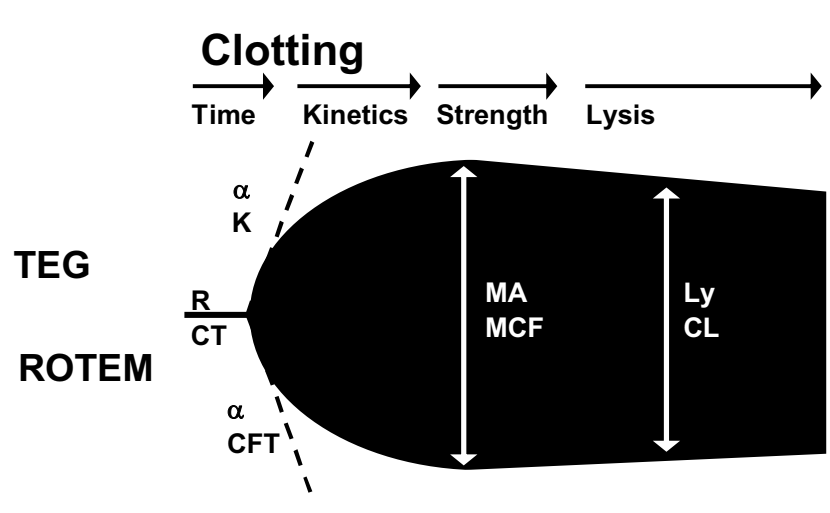

Figure I

Schematic TEG (upper part)/ROTEM (lower part) trace indicating the commonly reported variables reaction time $(\mathrm{R})$ /clotting time $(\mathrm{CT})$, clot formation time (K, CFT), alpha angle $(\alpha)$, maximum amplitude (MA)/maximum clot firmness (MCF) and lysis (Ly)/ clot lysis (CL).

generated from normal as compared to different pathological states are shown in Figure 2.

VHA can either be performed bedside using native nonanticoagulated blood if the sample is analyzed within 5 min or it can be performed in a laboratory setting, where citrated blood samples are employed [32]. The technical stability of the VHA analysis is demonstrated by day-today variation $(\mathrm{CV} \%)$ of $5-15 \%$ for the different parameters $[32,33]$.

Compared to RCoT, VHA has several advantages. First, the evaluation of the coagulation system in whole blood allows assessment of the combined influence of circulating plasmatic and cellular (platelets, RBC, leukocytes) elements on clot formation, including platelet function. Second, the end-point is clinically relevant, i.e. clotting in
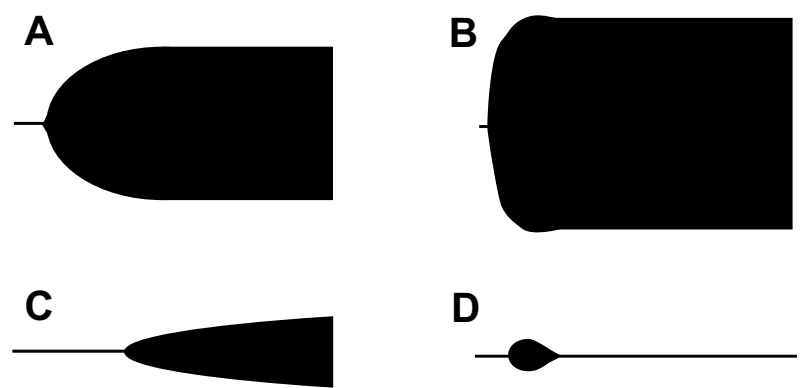

Figure 2

Schematic presentation of various VHA tracings: $A$ ) Normal, B) Hypercoagulability, C) Hypocoagulability (thrombocytopenia/pathy) and D) Primary hyperfibrinolysis. 
Table I: Nomenclature of TEG and ROTEM

\begin{tabular}{|c|c|c|}
\hline Parameter & TEG ${ }^{\circledR}$ & ROTEM $^{\circledR}$ \\
\hline \multicolumn{3}{|l|}{ Clot time } \\
\hline Period to $2 \mathrm{~mm}$ amplitude & $\mathrm{R}$ (reaction time) & CT (clotting time) \\
\hline \multicolumn{3}{|l|}{ Clot kinetics } \\
\hline Period from 2-20 mm amplitude & K (kinetics) & CFT (clot formation time) \\
\hline$\alpha$-angle & $\alpha$ (slope between $\mathrm{R}$ and $\mathrm{K}$ ) & $\alpha$ (slope of tangent at $2 \mathrm{~mm}$ amplitude) \\
\hline \multicolumn{3}{|l|}{ Clot strength } \\
\hline Maximum strength & MA (maximum amplitude) & MCF (maximum clot firmness) \\
\hline Clot elasticity & G & MCE (maximum clot elasticity) \\
\hline \multicolumn{3}{|l|}{ Clot lysis } \\
\hline Lysis (at fixed time) & Ly30, Ly60 (amplitude reduction 30/60 min after MA) & $\begin{array}{l}\text { CL30, CL60 } \\
\text { (amplitude reduction } 30 / 60 \text { min after MCF) }\end{array}$ \\
\hline
\end{tabular}

whole blood (fibrin formation, clot retraction and fibrinolysis, Figure 2). Third, the results are available within a short time frame making them relevant to clinical decision-making.

\section{VHA and the cell-based model of haemostasis}

According to the cell-based model, haemostasis is described in three phases [34-36]: Initiation, amplification and propagation. During initiation, circulating activated coagulation factor (F) VII (FVIIa) forms a complex with exposed TF on injured endothelium, which in the amplification stage generates a small amount of thrombin that mainly activates the platelets. In the propagation phase the coagulation factors assemble on the activated platelets generating large amounts of thrombin ("thrombin burst"). The rate and peak of thrombin generation influences the clot structure and stability [37], by activating FXIII to FXIIIa, which cross links fibrinogen and further stabilizes the clot [38]. Furthermore, thrombin activates TAFI to TAFIa which prevents lysis of the fibrin clot [39].

The three different phases of cell-based haemostasis resulting in clot formation are reflected by the VHA. The structural changes in the clot along the VHA trace was recently investigated by scanning electron microscopy demonstrating that the R (TEG)/CT (ROTEM) corresponds to the initiation phase whereas $\mathrm{K}$ (TEG)/CFT (ROTEM) reflects the amplification phase [40]. Our group and others have demonstrated that the thrombin burst is reflected by the $\alpha$-angle (TEG/ROTEM), and determines the clot strength and stability $[41,42]$. The ability of VHA to reflect thrombin generation has profound clinical utility because coagulation factor deficiencies secondary to e.g. massive bleeding, dilution, consumption and thrombocytopenia/pathy result in impaired thrombin generation and impaired clot strength (MA (TEG), MCF (ROTEM)) [30,43]. The whole blood based VHA, therefore, reveals the contribution of all circulating plasmatic and cellular components, in their actual concentrations, to clot formation [44]. Importantly, enhanced fibrinolysis contributes significantly to bleeding in trauma patients as well as patients undergoing cardiac and liver surgery and patients with obstetric complications, and this condition is readily identified by VHA (Ly (TEG), CL (ROTEM)) [45]. In addition, VHA in vitro studies have evaluated the effects of hypothermia [46], acidosis [47], different crystalloids and colloids [48], pro-haemostatic [49] and antifibrinolytic drugs [50], with results being highly relevant for the clinical setting.

\section{VHA in the surgical setting}

In the last 25 years, more than 20 clinical studies reporting on the benefit of using VHA when compared to RCoT to identify coagulopathy and guide transfusion therapy have been published (Table 2). The studies include three randomized clinical trials and involve more than 4,500 patients undergoing major surgery. The majority of studies have been performed in patients undergoing liver or cardiac surgery [51-57], all reporting of the benefit of using VHA when compared to RCoT, evidenced by reductions in transfusion requirements and need for re-exploration and improved ability to predict the need for blood transfusion in patients with VHA-guided therapy. Importantly, no study have to date reported a benefit of employing plasma-based RCoT to predict bleeding or guide transfusion therapy, when compared to VHA, supporting the scientific rationale of whole blood viscoelastic assays in this setting.

\section{Massive transfusion}

Our group reported the effect on mortality of guiding transfusion therapy in massively bleeding patients $(\mathrm{n}=$ $832,21 \%$ trauma patients) by VHA as compared to RCoT. Patients treated according to the VHA results received more FFP and more platelets and had significantly lower 30 -day mortality as compared to controls (20\% vs. $32 \%)$ [58].

It is intriguing that the increased amount of plasma and platelets administered based on the VHA results are asso- 
Table 2: Studies evaluating the effect of TEG vs. routine coagulation tests (RCoT) on haemostasis in surgical patients

\begin{tabular}{|c|c|c|c|c|}
\hline Author & Patients & No. & Study type & Major conclusions \\
\hline Kang (1985) & Liver surgery & 66 & $\mathrm{RC}$ & $\begin{array}{l}\text { VHA based therapy reduced blood and fluid infusion volume by } 33 \% \text { vs. } \\
\text { RCoT therapy }\end{array}$ \\
\hline McNicol (1994) & Liver surgery & 75 & $\mathrm{RC}$ & VHA enabled specific and selective use of FFP, PLT and cryoprecipitate \\
\hline Kang (1995) & Liver surgery & 80 & $\mathrm{RC}$ & $\begin{array}{l}\text { VHA identified clinically relevant fibrinolysis and enabled specific } \\
\text { pharmacological therapy }\end{array}$ \\
\hline Harding (1997) & Liver surgery & 55 & $\mathrm{RC}$ & $\begin{array}{l}\text { VHA-heparinase enabled identification of coagulopathy present under the } \\
\text { heparinisation }\end{array}$ \\
\hline Chau (1998) & Liver surgery & 20 & $\mathrm{PO}$ & $\begin{array}{l}\text { VHA predicted re-bleeding in cirrhotic patients with variceal bleeding, } \\
\text { whereas RCoT did not }\end{array}$ \\
\hline Tuman (1987) & Cardiac surgery & 87 & $\mathrm{RC}$ & VHA allowed rapid intraoperative diagnosis of coagulopathy during $C P B$ \\
\hline Spiess (1987) & Cardiac surgery & 38 & $\mathrm{RC}$ & $\begin{array}{l}\text { VHA was a better predictor ( } 87 \% \text { accuracy) of postoperative haemorrhage } \\
\text { and need for reoperation than RCoT ( } 30-51 \% \text { acuracy) }\end{array}$ \\
\hline Tuman (1989) & Cardiac surgery & 42 & $\mathrm{RC}$ & VHA, but not RCoT, predicted postoperative bleeding in patients post-CPB \\
\hline Essell (1993) & Cardiac surgery & 36 & PO & $\begin{array}{l}\text { VHA had higher specificity in predicting patients likely to benefit from FFP } \\
\text { and PLT therapy than RCoT }\end{array}$ \\
\hline Tuman (1994) & Cardiac surgery & 51 & RC & VHA-heparinase revealed post-CPB coagulopathy \\
\hline Spiess (1995) & Cardiac surgery & 1,079 & PI vs. RC & $\begin{array}{l}\text { VHA guided transfusion therapy significantly reduced overall incidence of } \\
\text { transfusion and total transfusions in the OR as compared to RCoT }\end{array}$ \\
\hline Shih (1997) & Cardiac surgery & 43 & $\mathrm{RC}$ & $\begin{array}{l}\text { VHA demonstrated higher sensitivity and specificity than RCoT for detecting } \\
\text { post-CPB bleeding }\end{array}$ \\
\hline Cherng (1998) & Cardiac surgery & 74 & $\mathrm{RC}$ & $\begin{array}{l}\text { Re-do patients demonstrated reduced pre-operative } \alpha \text {-angle and MA/MCF } \\
\text { was significantly reduced compared to patients not needing re-exploration }\end{array}$ \\
\hline Shore-Lesserson (1999) & Cardiac surgery & 105 & $\mathrm{RCS}$ & $\begin{array}{l}\text { VHA treated patients received fewer postoperative FFP and PLT } \\
\text { transfusions than patients treated based on PCoT }\end{array}$ \\
\hline Royston (200I) & Cardiac surgery & 90 & IS & $\begin{array}{l}\text { VHA guided transfusion therapy reduced the need for FFP and PLT threefold } \\
\text { vs. RCoT }\end{array}$ \\
\hline Manikappa (200I) & Cardiac surgery & 150 & $\mathrm{RCS}$ & $\begin{array}{l}\text { VHA had higher accuracy than RCoT to predict patients developing } \\
\text { excessive postoperative bleeding and significantly reduced the need for RBC, } \\
\text { FFP and PLT transfusions }\end{array}$ \\
\hline Welsby (2006) & Cardiac surgery & 30 & $\mathrm{PO}$ & $\begin{array}{l}\text { VHA MA/MCF showed better correlation with postoperative bleeding than } \\
\text { RCOT }\end{array}$ \\
\hline Anderson $(2006)^{*}$ & Cardiac surgery & 990 & PI vs. RC & $\begin{array}{l}\text { VHA guided therapy reduced the need for RBC, FFP and PLT as compared } \\
\text { to RCoT directed therapy }\end{array}$ \\
\hline Westbrook (2008) & Cardiac surgery & 69 & $\mathrm{RC}$ & $\begin{array}{l}\text { VHA-based management reduced total product usage by } 58.8 \% \text { in the study } \\
\text { group vs. RCoT group }\end{array}$ \\
\hline Reinhöfer (2008)* & Cardiac surgery & 150 & $\mathrm{RC}$ & $\begin{array}{l}\text { Clot strength, but not RCoT, had the highest predictive value for excess } \\
\text { postoperative blood loss }\end{array}$ \\
\hline Johansson (2009) & Massive transfusion & 832 & PI vs. RC & $\begin{array}{l}\text { VHA guided therapy reduced mortality from } 31 \% \text { to } 20 \% \text { in massively } \\
\text { bleeding patients }\end{array}$ \\
\hline
\end{tabular}

*ROTEM, RCoT = routine coagulation tests, $\mathrm{PO}=$ Prospective observational study, $\mathrm{RC}=$ Retrospective cohort study, $\mathrm{RCS}=\mathrm{Randomised}$ clinical study, PI vs. RC = Prospective interventional study vs. retrospective controls, IS = Interventional study

ciated with improved survival, in alignment with retrospective findings from the trauma setting [59] as well as the implementation of blind transfusion protocols [60].

\section{VHA in trauma}

A conserved physiologic haemostatic response, characterized by immediate activation of coagulation and fibrinolysis followed by subsequent fibrinolytic shutdown and later reactivation is often observed in trauma patients [61]. Post-traumatic coagulopathy is classically described as dysfunction and/or consumption of coagulation factors and platelets due to dilution, hypothermia and acidosis i.e., "the bloody viscious cycle" and the ability of VHA to identify these conditions has been extensively reported $[22,23,58,62-70]$. At present, 10 studies including more than 700 patients have evaluated VHA in trauma patients (Table 3).

Kaufmann et al. found that in 69 patients with blunt trauma, 65\% displayed hypercoagulability upon arrival at the emergency department (ED) whereas only $10 \%$ were hypocoagulable. Interestingly, a hypocoagulable TEG was associated with increased ISS and only ISS and VHA, not RCoT, was predictive for early transfusion [62]. Schreiber and colleagues [63] also found that hypercoagulability, as evaluated by VHA, was frequent $(62 \%)$ in trauma patients $(\mathrm{n}=65)$ upon arrival at the ED, and that this correlated with increased thrombin-antithrombin (TAT) complex generation. APTT, PT and platelet count where within normal limits and could, hence, not identify a hypercoagula- 
Table 3: Studies evaluating VHA in trauma patients

\begin{tabular}{|c|c|c|c|c|c|}
\hline Author & No. & ISS & Study type & Major conclusions & Ref. \\
\hline Kaufman (1997) & 69 & $13 / 29$ & RS & $\begin{array}{l}\text { Moderately injured patients (ISS I3) were hypercoagulable whereas severely injured (ISS 29) } \\
\text { patients were hypocoagulable according to VHA }\end{array}$ & {$[51]$} \\
\hline Schreiber (2005) & 65 & 23 & RS & $\begin{array}{l}62 \% \text { of the patients where hypercoagulable Ist day of trauma according to VHA which is } \\
\text { more sensitive to identify this state than RCoT. }\end{array}$ & {$[52]$} \\
\hline Rugeri (2007) & 90 & 22 & $\mathrm{PO}$ & $\begin{array}{l}\text { VHA rapidly detects systemic changes of in vivo coagulation in trauma patients, and it might } \\
\text { be a helpful device in guiding transfusion. }\end{array}$ & {$[76]$} \\
\hline Plotkin (2008) & 44 & 21 & RS & VHA is a more accurate indicator of transfusion requirements than PT, APTT and INR & [77] \\
\hline Levrat (2008) & 87 & $20 / 75$ & PO & $\begin{array}{l}\text { VHA provides rapid and accurate detection of hyperfibrinolysis in severely injured trauma } \\
\text { patients }\end{array}$ & [78] \\
\hline Schöchl (2009) & 33 & 47 & PO & $\begin{array}{l}\text { VHA based diagnosis of hyperfibrinolysis predicted outcome in severely injured trauma } \\
\text { patients }\end{array}$ & [79] \\
\hline Carroll (2009) & 161 & 20 & PO & $\begin{array}{l}\text { Abnormal VHA parameters correlated with fatality. Coagulopathy as evaluated by VHA was } \\
\text { present already on the scene of accident. }\end{array}$ & {$[80]$} \\
\hline Jaeger (2009) & 20 & ?? & RS & RapidTEG provides earlier detection of coagulopathy than standard VHA and RCoT & {$[81]$} \\
\hline Park (2009) & 78 & 20 & PO & VHA detected hypercoagulability and this was not seen with RCoT in trauma patients & [82] \\
\hline Kashuk (2009) & 44 & 29 & RS & RapidTEG may effectively guide transfusion therapy in trauma patients & [83] \\
\hline
\end{tabular}

$\mathrm{RCoT}=$ routine coagulation tests, $\mathrm{RS}=$ Retrospective study, $\mathrm{PO}=$ Prospective observational study

ble state. Rugeri and colleagues [64] investigated 88 trauma patients and compared their VHA results with that of healthy subjects. They found that trauma patients demonstrated evidence of hypocoagulability, and that this was restricted to those trauma patients also being coagulopathic with RCoT.

Recently, Carroll and colleagues [65] addressed the acute post-traumatic coagulopathy, reported by Brohi et al., $[2,8,9]$ by VHA analyses of samples obtained at the scene of accident and upon arrival in the ED in 161 trauma patients. Interestingly, they found that that the clot forming parameters demonstrated hypocoagulability and correlated with fatality, whereas none of the RCoT demonstrated such a correlation. This indicates that VHA is more sensitive in reflecting clinically relevant coagulopathies than RCoT. This has important implications, since the VHA result is available within a short time frame as interventions aiming at normalising the VHA profile and hence the coagulopathy, can be instituted early during resuscitation. The VHA results of acute post-traumatic coagulopathy presented by Carroll et al. do not, however, corroborate the frequency of hyperfibrinolysis reported by Brohi et al. [8]. Only three patients (2\%) demonstrated evidence of increased fibrinolysis compared to the hyperfibrinolysis described in the cohort of Brohi, using Ddimer as a marker of fibrinolysis. Levrat and colleagues [66] reported in a cohort of 89 trauma patients that 5 (6\%) showed evidence of increased fibrinolysis and that this correlated with euglobuline lysis time. In both the study of Carroll et al. and Levrat et al., hyperfibrinolysis was identified in the most severely injured patients and was associated with increased mortality rate confirming that although rare, this is a very serious condition. A unique feature of VHA is its ability to identify patients with increased fibrinolysis. This enables initiation of specific anti-fibrinolytic therapy, which is associated with decreased blood loss and/or transfusion requirements in non-trauma settings [71]. The role of this therapy in trauma patients [72] is currently under clinical evaluation http://www.crash2.lshtm.ac.uk/.

In a retrospective review of 44 combat patients with penetrating trauma Plotkin et al. [23] reported that VHA was a more accurate indicator of blood product requirements than PT, APTT, and INR. They suggested that VHA aided by platelet count and haematocrit should guide blood transfusion requirements. This is in alignment with Martini and colleagues [22] who demonstrated that VHA was superior than PT, APTT, and Activated Clotting Time in detecting clinically relevant clotting abnormalities after hypothermia, haemorrhagic shock and resuscitation in pigs.

Recently Jaeger and colleagues [67] reported of a modification of the VHA (TEG) where the activator kaolin was substituted with TF (RapidTEG). In patients sustaining major blunt trauma they investigated the time from ED arrival to the results of standard TEG, RapidTEG and RCoT were available. RapidTEG was available significantly faster (19.2 $\mathrm{min}$ vs. $29.9 \mathrm{~min}$ for kaolin TEG and $34.1 \mathrm{~min}$ for RCoT). On average the time until the results were available was reduced by approximately $50 \%$ for RapidTEG as compared to standard TEG, which may be of clinical relevance.

\section{VHA limitations}

Important limitations of the VHA exist and should be taken into consideration when interpreting the results of the analysis. Firstly, though it is possible to adjust the tem- 
perature at which the blood sample is analysed, VHA is routinely performed at $37^{\circ} \mathrm{C}$ and therefore the effect of hypothermia will not be recognised $[73,74]$. Secondly, the coagulation activators employed results in thrombin formation, which masks the possible inhibition that antithrombotic agents such as aspirin, NSAID, clopidogrel and eptifibatide may have on the platelets ability to aggregate [75]. Consequently, a normal VHA profile does not rule out clinically significant platelet inhibition. Thirdly, the endothelial contribution to haemostasis is not displayed in VHA and therefore, conditions affecting the endothelium such as von Willebrand disease (vWD, quantitative or qualitative defects in vWF and, hence inability of the platelets to adhere to the endothelium), cannot be investigated. If these causes of abnormal bleeding can be excluded, then a normal VHA trace along with clinically significant bleeding necessitating blood transfusion is suspect of a surgical cause. Thus, our group found $97 \%$ predictability by VHA in identifying a surgical cause of bleeding in postoperative non-cardiac patients with ongoing transfusion requirements [68].

\section{VHA future perspectives in trauma}

Recently, the concept of acute traumatic coagulopathy (ATC) was introduced by Brohi et al. $[2,8,9,13]$ based on the observations that coagulopathy, as evaluated by increased PT, APTT and D-dimer levels, was present in trauma patients already upon arrival to the hospital. ATC was independent of traditional causes of coagulopathy but occurred only in patients with evident hypoperfusion. When evaluating trauma patients upon arrival at ED with VHA characteristic profiles are found that are related to ISS and mortality. In patients with minor trauma/tissue injury a normal VHA trace is seen (Figure 2A) whereas in patients with moderate trauma (ISS between 10-20) hypercoagulability is seen (Figure 2B). In patients with severe injury (ISS 20-35), an increased frequency of hypocoagulability is seen (Figure 2C) whereas patients with massive tissue injury (ISS above 30) hyperfibrinolysis is seen (Figure 2D). The different VHA traces indicate that different treatment strategies may be appropriate and this warrants further investigation.

\section{Conclusion}

Death due to trauma is the leading cause of lost life years worldwide, with haemorrhage being responsible for 30$40 \%$ of trauma mortality and accounting for almost $50 \%$ of the deaths the initial $24 \mathrm{~h} \mathrm{[5].} \mathrm{There} \mathrm{is} \mathrm{emerging} \mathrm{con-}$ sensus that plasma-based assays are inappropriate for monitoring coagulopathy and guide transfusion therapy in trauma $[17,18]$, and the cell-based model of haemostasis [21,34-36] provides a reliable explanation for this notion. Clinical studies including more than 5000 surgical and/or trauma patients have reported on the benefit of using VHA when compared to RCoT to identify coagulop- athy and guide transfusion therapy. However, at present no VHA guided transfusion therapy has been prospectively and independently validated in trauma patients, which is highly warranted.

\section{Competing interests}

PJ has received unrestricted research grants from Haemoscope Corp. Niles IL, USA. The other authors declare that they have no competing interests'.

\section{Authors' contributions}

PJ, SO conducted the MEDLINE search for relevant publications related to VHA. PJ, SO, LB, TS conducted review of the searched publications and jointly decided which to be included in the review. PJ, SO wrote the first draft of the manuscript. SO designed the figures for the manuscript. PJO SO, LB, TS developed the tables. All authors read and approved the final manuscript.

\section{References}

I. Hess JR, Brohi K, Dutton RP, Hauser CJ, Holcomb JB, Kluger Y, Mackway-Jones K, Parr MJ, Rizoli SB, Yukioka T, Hoyt DB, Bouillon B: The coagulopathy of trauma: a review of mechanisms. J Trauma 2008, 65:748-754.

2. Brohi K, Cohen MJ, Davenport RA: Acute coagulopathy of trauma: mechanism, identification and effect. Curr Opin Crit Care 2007, 1 3:680-685.

3. Hoyt DB, Dutton RP, Hauser CJ, Hess JR, Holcomb JB, Kluger Y, Mackway-Jones K, Parr MJ, Rizoli SB, Yukioka T, Bouillon B: Management of coagulopathy in the patients with multiple injuries: results from an international survey of clinical practice. J Trauma 2008, 65:755-764.

4. Malone DL, Hess JR, Fingerhut A: Massive transfusion practices around the globe and a suggestion for a common massive transfusion protocol. I Trauma 2006, 60:S9I-S96.

5. Geeraedts LM Jr, Kaasjager HA, van Vugt AB, Frolke JP: Exsanguination in trauma: $A$ review of diagnostics and treatment options. Injury 2009, 40: II-20.

6. Johansson $\mathrm{PI}$, Hansen $\mathrm{MB}$, Sorensen $\mathrm{H}$ : Transfusion practice in massively bleeding patients: time for a change? Vox Sang 2005, 89:92-96.

7. Holcomb JB, Jenkins D, Rhee P, Johannigman J, Mahoney P, Mehta S, Cox ED, Gehrke MJ, Beilman GJ, Schreiber M, Flaherty SF, Grathwohl KW, Spinella PC, Perkins JG, Beekley AC, McMullin NR, Park MS, Gonzalez EA, Wade CE, Dubick MA, Schwab CW, Moore FA, Champion HR, Hoyt DB, Hess JR: Damage control resuscitation: directly addressing the early coagulopathy of trauma. J Trauma 2007, 62:307-310.

8. Brohi K, Cohen MJ, Ganter MT, Matthay MA, Mackersie RC, Pittet JF: Acute traumatic coagulopathy: initiated by hypoperfusion: modulated through the protein C pathway? Ann Surg 2007, 245:812-818.

9. Brohi K, Cohen MJ, Ganter MT, Schultz MJ, Levi M, Mackersie RC, Pittet JF: Acute coagulopathy of trauma: hypoperfusion induces systemic anticoagulation and hyperfibrinolysis. J Trauma 2008 , 64: $1211-1217$.

10. Shapiro S, Sherwin B, Gordimer H: Postoperative thromboembolization: The platelet count and the prothrombin time after surgical operations: A simpe method for detecting reductions and elevations of the prothrombin concentration (or activity) of the blood plasma. Ann Surg 1942, I I 6: I 75- I 83.

II. Proctor RR, Rapaport SI: The partial thromboplastin time with kaolin. A simple screening test for first stage plasma clotting factor deficiencies. Am J Clin Pathol 196I, 36:212-219.

12. Aoki N, Wall MJ, Demsar J, Zupan B, Granchi T, Schreiber MA, Holcomb JB, Byrne M, Liscum KR, Goodwin G, Beck JR, Mattox KL: Predictive model for survival at the conclusion of a damage control laparotomy. Am J Surg 2000, I 80:540-544. 
13. Brohi K, Singh J, Heron M, Coats T: Acute traumatic coagulopathy. J Trauma 2003, 54: I I27-II30.

14. MacLeod JB, Lynn M, McKenney MG, Cohn SM, Murtha M: Early coagulopathy predicts mortality in trauma. J Trauma 2003, 55:39-44.

15. Segal JB, Dzik WH: Paucity of studies to support that abnormal coagulation test results predict bleeding in the setting of invasive procedures: an evidence-based review. Transfusion 2005, 45: | $4 \mid 3-1425$.

16. Levi M, Opal SM: Coagulation abnormalities in critically ill patients. Crit Care 2006, 10:222.

17. Fries D, Innerhofer P, Schobersberger W: Time for changing coagulation management in trauma-related massive bleeding. Curr Opin Anaesthesiol 2009, 22:267-274.

18. Bartal C Yitzhak A: The role of thromboelastometry and recombinant factor VIla in trauma. Curr Opin Anaesthesiol 2009, 22:28I-288.

19. Macfarlane RG: An enzyme cascade in the blood clotting mechanism, and its function as a biochemical amplifier. Nature 1964, 202:498-499.

20. Davie EW, Ratmoff OD: Waterfall sequence for intrinsic blood clotting. Science 1964, 145:1310-1312.

21. Monroe DM, Roberts HR, Hoffman M: Platelet procoagulant complex assembly in a tissue factor-initiated system. Br J Haematol 1994, 88:364-37|

22. Martini WZ, Cortez DS, Dubick MA Park MS, Holcomb JB: Thrombelastography is Better Than PT, aPTT, and Activated Clotting Time in Detecting Clinically Relevant Clotting Abnormalities After Hypothermia, Hemorrhagic Shock and Resuscitation in Pigs. J Trauma 2008, 65:535-543.

23. Plotkin AJ, Wade CE, Jenkins DH, Smith KA, Noe JC, Park MS, Perkins JG, Holcomb JB: A reduction in clot formation rate and strength assessed by thrombelastography is indicative of transfusion requirements in patients with penetrating injuries. J Trauma 2008, 64:S64-S68.

24. Gravlee GP, Arora S, Lavender SW, Mills SA, Hudspeth AS, Cordell AR, James RL, Brockschmidt JK, Stuart J]: Predictive value of blood clotting tests in cardiac surgical patients. Ann Thorac Surg 1994, 58:216-22I.

25. Murray D, Pennell B, Olson J: Variability of prothrombin time and activated partial thromboplastin time in the diagnosis of increased surgical bleeding. Transfusion 1999, 39:56-62.

26. Hartert $\mathrm{H}$ : Blutgerinnungsstudien mit der thrombelastographie, einem neuen untersuchungsverfahren. Klin Wochenschr 1948, 26:577-583

27. Salooja N, Perry DJ: Thrombelastography. Blood Coagul Fibrinolysis 200I, I 2:327-337.

28. Luddington RJ: Thrombelastography/thromboelastometry. Clin Lab Haematol 2005, 27:8I-90.

29. Chandler WL: The thromboelastography and the thromboelastograph technique. Semin Thromb Hemost 1995, 2 I (Suppl 4): $1-6$.

30. Di Benedetto P, Baciarello M, Cabetti L, Martucci M, Chiaschi A, Bertini L: Thrombelastography. Present and future perspectives in clinical practice. Minerva Anestesiol 2003, 69:50I-5I5.

31. Ganter MT, Hofer CK: Coagulation monitoring: current techniques and clinical use of viscoelastic point-of-care coagulation devices. Anesth Analg 2008, 106:1366-1375.

32. Johansson PI, Bochsen L, Andersen S, Viuff D: Investigation of the effect of kaolin and tissue factor-activated citrated whole blood, on clot forming variables, as evaluated by thromboelastography. Transfusion 2008, 48:2377-2383.

33. Jennings I, Kitchen DP, Woods TA, Kitchen S, Walker ID: Emerging technologies and quality assurance: the United Kingdom National External Quality Assessment Scheme perspective. Semin Thromb Hemost 2007, 33:243-249.

34. Roberts HR, Monroe DM, Escobar MA: Current concepts of hemostasis: implications for therapy. Anesthesiology 2004, 100:722-730.

35. Monroe DM, Hoffman M, Roberts HR. Platelets and thrombin generation. Arterioscler Thromb Vasc Biol 2002, 22:138I-1389.

36. Hoffman MM, Monroe DM: Rethinking the coagulation cascade. Curr Hematol Rep 2005, 4:39I-396.

37. Allen GA, Wolberg AS, Oliver JA, Hoffman M, Roberts HR, Monroe DM: Impact of procoagulant concentration on rate, peak and total thrombin generation in a model system. I Thromb Haemost 2004, 2:402-4I3.

38. Lorand L: Factor XIII: structure, activation, and interactions with fibrinogen and fibrin. Ann N Y Acad Sci 200I, 936:29I-3II.

39. Bouma BN, Meijers JC: Role of blood coagulation factor $\mathbf{X I}$ in downregulation of fibrinolysis. Curr Opin Hematol 2000, 7:266-272.

40. Kawasaki J, Katori N, Kodaka M, Miyao H, Tanaka KA: Electron microscopic evaluations of clot morphology during thrombelastography. Anesth Analg 2004, 99: I440-I 444.

4I. Johansson PI, Svendsen MS, Salado J, Bochsen L, Kristensen AT: Investigation of the thrombin-generating capacity, evaluated by thrombogram, and clot formation evaluated by thrombelastography of platelets stored in the blood bank for up to 7 days. Vox Sang 2008, 94: I 13-118.

42. Rivard GE, Brummel-Ziedins KE, Mann KG, Fan L, Hofer A, Cohen E: Evaluation of the profile of thrombin generation during the process of whole blood clotting as assessed by thrombelastography. J Thromb Haemost 2005, 3:2039-2043.

43. Sorensen B, Ingerslev J: Tailoring haemostatic treatment to patient requirements - an update on monitoring haemostatic response using thrombelastography. Haemophilia 2005 , I I(Suppl I): I-6.

44. Chakroun T, Gerotziafas GT, Seghatchian J, Samama MM, Hatmi M, Elalamy I: The influence of fibrin polymerization and plateletmediated contractile forces on citrated whole blood thromboelastography profile. Thromb Haemost 2006, 95:822-828.

45. Nielsen VG, Cohen BM, Cohen E: Elastic modulus-based thrombelastographic quantification of plasma clot fibrinolysis with progressive plasminogen activation. Blood Coagul Fibrinolysis 2006, 17:75-8I.

46. Kheirabadi BS, Crissey JM, Deguzman R, Holcomb JB: In vivo bleeding time and in vitro thrombelastography measurements are better indicators of dilutional hypothermic coagulopathy than prothrombin time. J Trauma 2007, 62:1352-I359.

47. Viuff D, Lauritzen B, Pusateri AE, Andersen S, Rojkjaer R, Johansson PI: Effect of haemodilution, acidosis, and hypothermia on the activity of recombinant factor VIla (NovoSeven(R)). Br J Anaesth 2008, 101:324-331.

48. Jones SB, Whitten CW, Despotis G], Monk TG: The influence of crystalloid and colloid replacement solutions in acute normovolemic hemodilution: a preliminary survey of hemostatic markers. Anesth Analg 2003, 96:363-8.

49. Hendriks HG, Meijer K, de Wolf JT, Porte RJ, Klompmaker IJ, Lip H, Slooff MJ, van der Meer MJ: Effects of recombinant activated factor VII on coagulation measured by thromboelastography in liver transplantation. Blood Coagul Fibrinolysis 2002, 13:309-3 I3.

50. Nielsen VG, Cankovic L, Steenwyk BL: Epsilon-aminocaproic acid inhibition of fibrinolysis in vitro: should the 'therapeutic' concentration be reconsidered? Blood Coagul Fibrinolysis 2007 18:35-39.

5I. Kang YG, Martin DJ, Marquez J, Lewis JH, Bontempo FA, Shaw BW Jr, Starzl TE, Winter PM: Intraoperative changes in blood coagulation and thrombelastographic monitoring in liver transplantation. Anesth Analg 1985, 64:888-896.

52. McNicol PL, Liu G, Harley ID, McCall PR, Przybylowski GM, Bowkett J, Angus PW, Hardy KJ, Jones RM: Patterns of coagulopathy during liver transplantation: experience with the first 75 cases using thrombelastography. Anaesth Intensive Care 1994, 22:659-665

53. Spiess BD, Gillies BS, Chandler W, Verrier E: Changes in transfusion therapy and reexploration rate after institution of a blood management program in cardiac surgical patients. J Cardiothorac Vasc Anesth 1995, 9:168-173.

54. Shore-Lesserson L, Manspeizer HE, DePerio M, Francis S, Vela-Cantos $F$, Ergin MA: Thromboelastography-guided transfusion algorithm reduces transfusions in complex cardiac surgery. Anesth Analg 1999, 88:312-319.

55. Manikappa S, Mehta Y, Juneja R, Trehan N: Changes in transfusion therapy guided by thromboelastograph in cardiac surgery. Ann Card Anaesth 200I, 4:2I-27.

56. Anderson L, Quasim I, Soutar R, Steven M, Macfie A, Korte W: An audit of red cell and blood product use after the institution of thromboelastometry in a cardiac intensive care unit. Transfus Med 2006, 16:31-39. 
57. Welsby IJ, Jiao K, Ortel TL, Brudney CS, Roche AM, Bennett-Guerrero E, Gan T]: The kaolin-activated Thrombelastograph predicts bleeding after cardiac surgery. J Cardiothorac Vasc Anesth 2006, 20:531-535.

58. Johansson PI, Stensballe J: Effect of Haemostatic Control Resuscitation on mortality in massively bleeding patients: a before and after study. Vox Sang 2009, 96: I II-II8.

59. Holcomb JB, Wade CE, Michalek JE, Chisholm GB, Zarzabal LA, Schreiber MA, Gonzalez EA, Pomper G], Perkins JG, Spinella PC, Williams KL, Park MS: Increased plasma and platelet to red blood cell ratios improves outcome in 466 massively transfused civilian trauma patients. Ann Surg 2008, 248:447-458.

60. Cotton BA, Gunter OL, Isbell J, Au BK, Robertson AM, Morris JA Jr, St Jacques P, Young PP: Damage control hematology: the impact of a trauma exsanguination protocol on survival and blood product utilization. J Trauma 2008, 64: I I77-I I 82.

61. Gando S: Disseminated intravascular coagulation in trauma patients. Semin Thromb Hemost 200I, 27:585-592.

62. Kaufmann CR, Dwyer KM, Crews JD, Dols SJ, Trask AL: Usefulness of thrombelastography in assessment of trauma patient coagulation. J Trauma 1997, 42:716-720.

63. Schreiber MA, Differding J, Thorborg P, Mayberry JC, Mullins RJ: Hypercoagulability is most prevalent early after injury and in female patients. J Trauma 2005, 58:475-480.

64. Rugeri L, Levrat A, David JS, Delecroix E, Floccard B, Gros A, Allaouchiche B, Negrier C: Diagnosis of early coagulation abnormalities in trauma patients by rotation thrombelastography. J Thromb Haemost 2007, 5:289-295.

65. Carroll RC, Craft RM, Langdon RJ, Clanton CR, Snider CC, Wellons DD, Dakin PA, Lawson CM, Enderson BL, Kurek SJ: Early evaluation of acute traumatic coagulopathy by thrombelastography. Transl Res 2009, 154:34-39.

66. Levrat A, Gros A, Rugeri L, Inaba K, Floccard B, Negrier C, David JS: Evaluation of rotation thrombelastography for the diagnosis of hyperfibrinolysis in trauma patients. $\mathrm{Br} J$ Anaesth 2008 , 100:792-797.

67. Jeger V, Zimmermann H, Exadaktylos AK: Can RapidTEG accelerate the search for coagulopathies in the patient with multiple injuries? J Trauma 2009, 66: |253- 2257.

68. Johansson PI: Treatment of massively bleeding patients: introducing real-time monitoring, transfusion packages and thrombelastography (TEGR). ISBT Science Series 2007 2:159-167.

69. Johansson PI, Bochsen L, Stensballe J, Secher NH: Transfusion packages for massively bleeding patients: The effect on clot formation and stability as evaluated by Thrombelastograph (TEG). Transfus Apher Sci 2008, 39:3-8.

70. Avikainen V: Coagulation disorders in severely and critically injured patients. Ann Chir Gynaecol 1977, 66:269-277.

7I. Henry DA, Carless PA, Moxey AJ, O'Connell D, Stokes BJ, McClelland B, Laupacis A, Fergusson D: Anti-fibrinolytic use for minimising perioperative allogeneic blood transfusion. Cochrane Database Syst Rev 2007:CD001886.

72. Coats T, Roberts I, Shakur H: Antifibrinolytic drugs for acute traumatic injury. Cochrane Database Syst Rev 2004:CD004896.

73. Douning LK, Ramsay MA, Swygert TH, Hicks KN, Hein HA, Gunning TC, Suit CT: Temperature corrected thrombelastography in hypothermic patients. Anesth Analg 1995, 81:608-6II.

74. Kettner SC, Sitzwohl C, Zimpfer M, Kozek SA, Holzer A, Spiss CK, Illievich UM: The effect of graded hypothermia (36 degrees $C$ 32 degrees $\mathbf{C}$ ) on hemostasis in anesthetized patients without surgical trauma. Anesth Analg 2003, 96:1772-6. table

75. Swallow RA, Agarwala RA, Dawkins KD, Curzen NP: Thromboelastography: potential bedside tool to assess the effects of antiplatelet therapy? Platelets 2006, 17:385-392.

76. Kang $Y$ : Thromboelastography in liver transplantation. Semin Thromb Hemost 1995, 21:34-44.

77. Harding SA, Mallett SV, Peachey TD, Cox DJ: Use of heparinase modified thrombelastography in liver transplantation. $\mathrm{Br}$ Anaesth 1997, 78:175-I79.

78. Chau TN, Chan YW, Patch D, Tokunaga S, Greenslade L, Burroughs AK: Thrombelastographic changes and early rebleeding in cirrhotic patients with variceal bleeding. Gut 1998, 43:267-27I.

79. Tuman KJ, Spiess BD, McCarthy RJ, Ivankovich AD: Effects of progressive blood loss on coagulation as measured by thrombelastography. Anesth Analg 1987, 66:856-863.
80. Spiess BD, Tuman KJ, McCarthy RJ, DeLaria GA, Schillo R, Ivankovich $A D$ : Thromboelastography as an indicator of post-cardiopulmonary bypass coagulopathies. J Clin Monit 1987, 3:25-30.

81. Tuman KJ, Spiess BD, McCarthy RJ, Ivankovich AD: Comparison of viscoelastic measures of coagulation after cardiopulmonary bypass. Anesth Analg 1989, 69:69-75.

82. Essell JH, Martin TJ, Salinas J, Thompson JM, Smith VC: Comparison of thromboelastography to bleeding time and standard coagulation tests in patients after cardiopulmonary bypass. Cardiothorac Vasc Anesth 1993, 7:410-4I5.

83. Tuman KJ, McCarthy RJ, Djuric M, Rizzo V, Ivankovich AD: Evaluation of coagulation during cardiopulmonary bypass with a heparinase-modified thromboelastographic assay. J Cardiothorac Vasc Anesth 1994, 8: I44-149.

Publish with Biomed Central and every scientist can read your work free of charge

"BioMed Central will be the most significant development for disseminating the results of biomedical research in our lifetime. "

Sir Paul Nurse, Cancer Research UK

Your research papers will be:

- available free of charge to the entire biomedical community

- peer reviewed and published immediately upon acceptance

- cited in PubMed and archived on PubMed Central

- yours - you keep the copyright 